\title{
On the Treatment Trains for Municipal Wastewater Reuse for Irrigation
}

\author{
Djamel Ghernaout ${ }^{1,2 *}$, Noureddine Elboughdiri ${ }^{1,3}$ \\ ${ }^{1}$ Chemical Engineering Department, College of Engineering, University of Ha'il, Ha'il, KSA \\ ${ }^{2}$ Chemical Engineering Department, Faculty of Engineering, University of Blida, Blida, Algeria \\ ${ }^{3}$ Département de Génie Chimique de Procédés, Laboratoire Modélisation, Analyse, et Commande des systèmes, Ecole Nationale \\ d’Ingénieurs de Gabès (ENIG), Rue Omar Ibn-Elkhattab, Gabès, Tunisia \\ Email: ${ }^{*}$ jamel_andalus@hotmail.com
}

How to cite this paper: Ghernaout, D. and Elboughdiri, N. (2020) On the Treatment Trains for Municipal Wastewater Reuse for Irrigation. Open Access Library Journal, 7: e6088.

https://doi.org/10.4236/oalib.1106088

Received: January 19, 2020

Accepted: February 14, 2020

Published: February 17, 2020

Copyright $\odot 2020$ by author(s) and Open Access Library Inc.

This work is licensed under the Creative Commons Attribution International License (CC BY 4.0).

http://creativecommons.org/licenses/by/4.0/

\begin{abstract}
Traditional urban wastewater treatment plants (UWTPs) are badly efficient in eliminating most contaminants of emerging concern (CECs), comprising antibiotics, antibiotic-resistant bacteria and antibiotic resistance genes (ARB \& ARGs). Such pollutants induce some worry for nature and human health, especially if UWTPs effluents are reused for crop irrigation. In all probability, traditional UWTPs will need extra advanced treatment stages to satisfy water quality limits for wastewater reuse. Recently, Rizzo and his co-workers [1] published an excellent review that aims to suggest potential advanced treatment solutions, especially concerning the elimination of CECs and ARB \& ARGs. They deeply assessed the performance of the best available technologies (BATs) for domestic wastewater treatment to decrease CECs and ARB \& ARGs. Especially, they evaluated ozonation, activated carbon adsorption, chemical disinfection, UV radiation, advanced oxidation processes (AOPs) and membrane filtration focusing on their capacity to efficiently eliminate CECs and ARB \& ARGs, as well as their benefits and disadvantages. This work focuses on likely treatment trains involving the aforesaid BATs. As concluded by Rizzo et al. [1] a one advanced treatment technique is not enough to reduce the liberation of chemical CECs and ARB \& ARGs and make wastewater reuse for crop irrigation safer; however, an impertinent integration of them and an appropriate controlling program would be needed. There is no miraculous BAT for treating wastewater for water reuse in agriculture. An appropriate combination of many techniques would be suggested following each case.
\end{abstract}




\section{Subject Areas}

Environmental Sciences

\section{Keywords}

Water Reuse, Treatment Trains (TTs), Contaminants of Emerging Concern (CECs), Antibiotic-Resistant Bacteria (ARB), Antibiotic Resistance Genes (ARGs), Best Available Technologies (BATs)

\section{Introduction}

Wastewater reuse stays one of the most significant options to traditional water sources to both (1) treat wastewater pollutants at their origin before their emanation in nature and (2) manage water lack [1] [2] [3] [4]. At most, about 1.2 billion people live in regions touched by grave water deficiency situations and 1.8 billion people are expected to be living in areas impacted by water lack by 2025 [1]. For irrigation in agriculture, wastewater reuse remains by far the most accepted end-use for recovered water [1] [5] [6]. Nevertheless, during the time that thinking through water lacks, wastewater reuse may induce public health hazards if treatment, storage, and piping are not appropriate especially in poor countries [7] [8]. More dangers reside in the microbial hazard (even if efficient disinfection methods are usually comprised in the treatment train (TT)) and contaminants of emerging concern (CECs), like pesticides, pharmaceuticals, illicit drugs, synthetic and natural hormones, personal care products, and resistant microorganisms (i.e. antibiotic-resistant bacteria and genes (ARB \& ARGs)) [9] [10] [11].

It is well established that traditional TTs in UWTPs are badly efficacious to completely eliminate CECs [12] [13] [14] [15], which are ultimately liberated into nature, forming a special worry if effluents are reused for crop irrigation. To eliminate CECs, advanced treatment stages must be applied in classical UWTPs [14] [16] [17] [18]. Nevertheless, although the impact of biological processes [14] [19] [20] [21] and advanced treatment technologies [16] [22]-[28] on chemical CECs has been discussed in many publications, fewer details are at hand regarding ARB \& ARGs and, most significantly, on feasible TTs merging many techniques to greatly manage such dares [1].

In their recent and comprehensive review, Rizzo et al. [1] presented and discussed the best available technologies (BATs) for advanced treatment of domestic wastewater, as well as potential TTs to dominate the liberation of CECs, comprising ARB \& ARGs, to treat wastewater for secure and likely reuse applications in agriculture. Most importantly, they discussed the capacity of ozonation, activated carbon adsorption, chemical oxidants/disinfectants, ultraviolet (UV) radiation, advanced oxidation processes (AOPs) [29] [30] [31] and membrane filtration [32] [33] [34] [35] [36] to remove CECs and ARB \& ARGs com- 
prising the benefits and disadvantages of such techniques. Then, they compared the aforesaid technologies for CECs related to crop uptake. Moreover, they assessed the probable TTs involving the above-discussed BATs for likely implementation. In the end, they summarized probable benefits, disadvantages, and recommendations of the suggested TTs.

This work focuses on the last part of the Rizzo et al. [1]'s review that concerns the conceivable TTs implying the above-mentioned BATs for likely implementation for water reuse in agriculture.

\section{Multi-Barrier Strategy for Safely Treated Wastewater Reuse in Agriculture}

\subsection{Treatment Trains (TTs) for a Safe Reuse}

To make wastewater reuse secure for crop irrigation, a multi-barrier procedure to wastewater treatment is required [37] [38] [39]. Such barriers have to involve standard techniques for municipal wastewater treatment (that is, primary mechanical pre-treatment, possible primary settling, biological treatment, etc.) and advanced treatments. Conceivable choices of TTs presenting diverse effluent qualities are shown in Figure 1.

The lowest treatment scheme for safe reuse must involve a traditional depth filtration downstream of a biological process (or an ultrafiltration (UF) membrane [40] as in case of membranebiological reactor (MBR), Figure 1(b)), pursued via a disinfectionstage with UV radiation (Figure 1(a)). This TT has to efficiently permit to handle standard factors (like biochemical oxygen demand (BOD), chemical oxygen demand (COD), total suspendedsolids (TSS), E. coli [41] [42] [43], etc.) put in wastewater reuse regulation and guidelines [1].

Chemical disinfection (especially via chlorine [44] [45] [46] [47] [48]) (Figure $1(c)$ ) is cheapercontrasted to other disinfection choices; however, the generation of disinfection by-products (DBPs) [49] [50] [51] [52] must be taken into account, and the TT may become costly contrasted to other solutions if DBPs are eliminated before reuse [1] [53].

It has to be mentioned that, chemical disinfectants (like chlorine), as well as an MBR with UF membrane and UV radiation, are deficiently efficacious in dealing with CECs [1].

As long as, if (i) the corresponding limit for bacterial indicators is so stringent that UV disinfection is not enough and/or (ii) CECs pollution has to be efficiently decreased, other more efficacious treatment techniques require to be adopted (Figures $1(\mathrm{~d})-(\mathrm{g}))$ [1].

In the middle of AOPs, ozonation and photochemical techniques presented good performances in reducing CECs and ARB. Especially, in the short term, ozonation and $\mathrm{UV} / \mathrm{H}_{2} \mathrm{O}_{2}$ methods are more interesting choices (Figure $1(\mathrm{~d})$ ) contrasted to other photo-driven AOPs to remove CECs as well as to efficiently demobilize pathogens [16] since:

1. Their performance has been established via numerous researches found in 


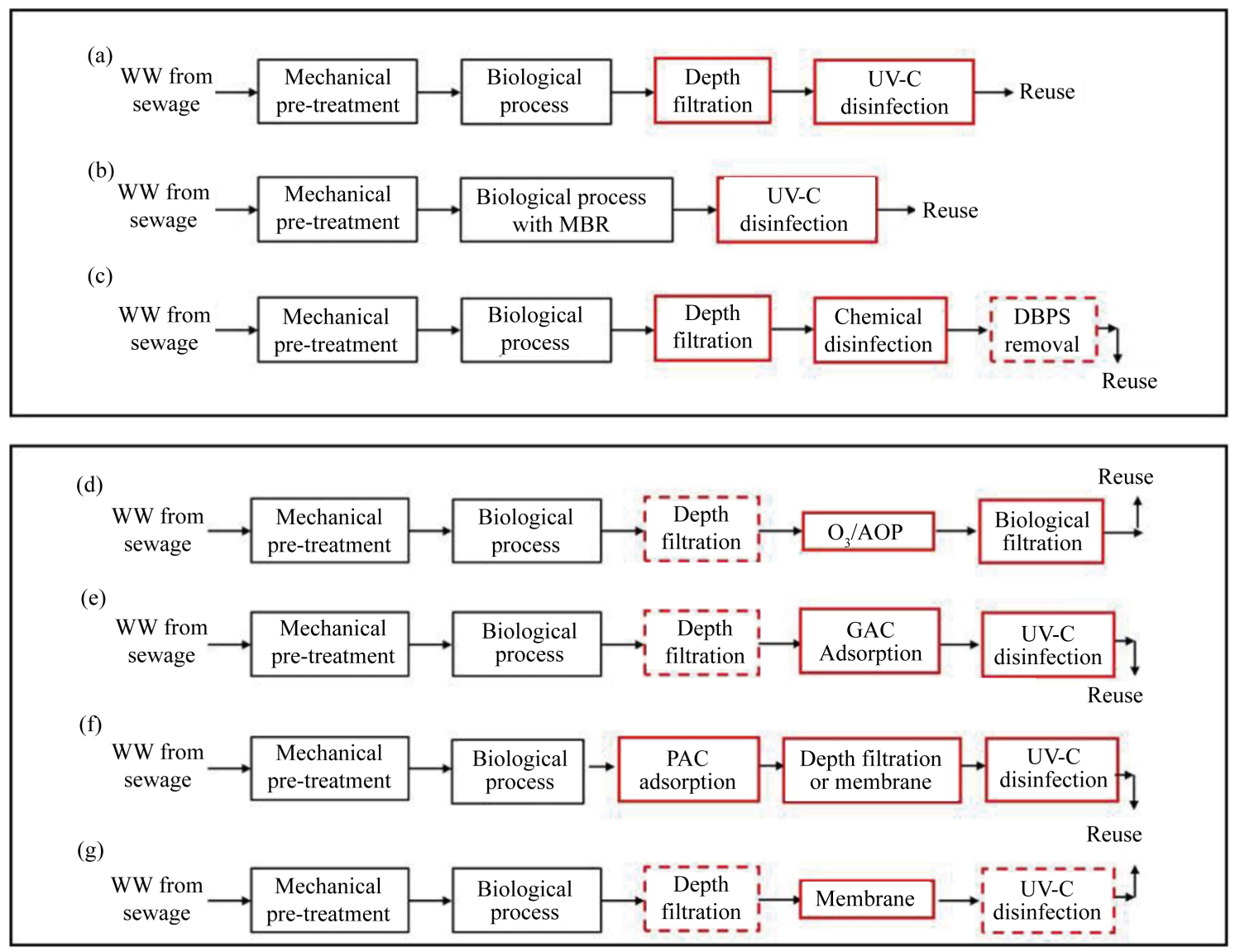

Figure 1. Different options of treatment trains (TTs) for urban wastewater reuse to address traditional parameters set in wastewater reuse regulation and guidelines (e.g., BOD, COD, TSS, E. coli etc.) (a, b, c) and to effectively remove CECs in addition to the typical parameters ( $\mathrm{d}, \mathrm{e}, \mathrm{f}, \mathrm{g}$ ). Advanced treatment in red lines; red dotted lines mean that process application should be evaluated case by case. "Biological process" followed by "depth filtration" may be replaced by "MBR" for TTs "d" and "e" [1].

publications. Nevertheless, ozonation requires much less energy contrasted to $\mathrm{UV} / \mathrm{H}_{2} \mathrm{O}_{2}$ remediation for the identical CEC decrease degree and illustrates full-scale implementation;

2. Other homogeneous photocatalytic techniques (like photo-Fenton) may need extra expenses (such as $\mathrm{pH}$ adjustment, chelating agents' addition) and/or have not yet been thoroughly studied (like UV/free chlorine, sulfate radical based AOPs, etc.);

3. Heterogeneous photocatalytic techniques until now have critical practical hindrances for full-scale utilization [1].

It should be mentioned that ozonation and AOPs basically necessitate biological post-treatment (i.e. biological sand or activated carbon filtration) to reduce biodegradable oxidation by-products and transformation products (Figure 1(d)). Rapid depth filtration or otherwisea dissolved air flotation treatment may be employed as a pretreatment technique just prior to AOP in the case that residual suspended solids should interfere with subsequent processes [1].

Adsorption on granular activated carbon (GAC) in packed reactors pursued 
by UV disinfection (in contrast to $\mathrm{O}_{3}$ and $\mathrm{UV} / \mathrm{H}_{2} \mathrm{O}_{2}$, adsorption is not a disinfection technology) is one more choice to enhance the quality of effluent wastewater prior to reuse (Figure $1(\mathrm{e})$ ). To prohibit GAC packed reactors from a rapid blocking and elevate back flushing periods, cloth or rapid sand filtration may be utilized to eliminate suspended solids prior to the adsorption method [1].

Provided that PAC adsorption is employed in integration with the biological method (via introducing PAC into the biological setup) or as a distinct component subsequently, either depth filtration and/or MF/UF membrane processes have to be utilized to eliminate residual PAC particles prior to discharge (Figure 1(f)). Like in GAC remediation, a UV disinfection must be put [1].

Finally, membrane filtration with NF or RO pursued by UV disinfectionis one more conceivable choice for advanced treatment of wastewater prior to reuse (Figure $1(\mathrm{~g})$ ). Pre-treatment via sand filtration may be implemented to reduce suspended solids to dominate membrane fouling, even if it is more frequent to filter settled effluent directly using MF or UF membranes. Further, MF and UF membranes give appropriate pre-treatment for the NF or RO stage (in such a situation ultimate disinfection via UV radiation is not required for crop irrigation). Most importantly, RO treatment would be also useful for crop irrigation thanks to the elimination of salts from the effluent. Nevertheless, for membrane techniques to be potential, there is a necessity of a thorough investigation of the appropriate treatment and/or recycling of concentrates on a case by case basis. Employing efficient concentrate treatment possesses the capacity to improve treatment performance, move to a near zero-liquid discharge and evade undesirable discharge of CEC [1].

\subsection{Benefits, Disadvantages, and Recommendations of the Treatment Trains (TTs)}

This debate aims to propose the "best available technologies (BATs) able to minimize the release of micro-contaminants including ARB \& ARGs, and biological risk, and fulfill requirements for safe reuse for crop irrigation" [1]. For all the TTs presented above, the main problems are listed in Table 1. As a result, and taking into account that no detailed comparative investigations handling CECs and ARB \& ARGs reduction via advanced treatment techniques are published [16], a comparative economic evaluation would be controversial. Especially, advanced treatment techniques have been compared in terms of either CECs elimination, costs, disinfection performance, ARB \& ARGs reduction, generation of DBPs and oxidation reaction products, and final toxicity; however, the total effect on nature via the simultaneous assessment of all these problems has not been examined [16].

\section{Conclusions}

From this work, the following conclusions can be drawn:

1) The safety of treated wastewater to be reused for crop irrigation is a relevant 
Table 1. Benefits, obstacles, and recommendations for each TT in Figure 1 [1].

\begin{tabular}{|c|c|c|c|}
\hline TT (advanced treatment) & Benefits & Obstacles & Recommendations \\
\hline a or b (UV) & $\begin{array}{l}\text { - Efficient disinfection } \\
\text { (comprising ARB demobilization) } \\
\text { - No DBPs generation contrasted to } \\
\text { chemical disinfection }\end{array}$ & $\begin{array}{l}\text { - Poor/no CECs elimination } \\
\text {-Partial elimination of ARGs }\end{array}$ & $\begin{array}{l}\text { - Compliance with local residual } \\
\text { bacterial density standards } \\
\text { should be evaluated }\end{array}$ \\
\hline c (chemical disinfection) & $\begin{array}{l}\text { Efficient disinfection } \\
\text { (comprising ARB } \\
\text { demobilization) }\end{array}$ & $\begin{array}{l}\text { - Poor/no reduction of CECs } \\
\text { and ARGs } \\
\text { - Generation of DBPs }\end{array}$ & $\begin{array}{l}\text { - Toxicity trials recommended } \\
\text { DBPs (following the } \\
\text { disinfectants utilized) must be } \\
\text { controlled }\end{array}$ \\
\hline $\begin{array}{l}\mathrm{d}\left(\mathrm{O}_{3} / \mathrm{AOP} \text { and biological }\right. \\
\text { post-treatment })\end{array}$ & 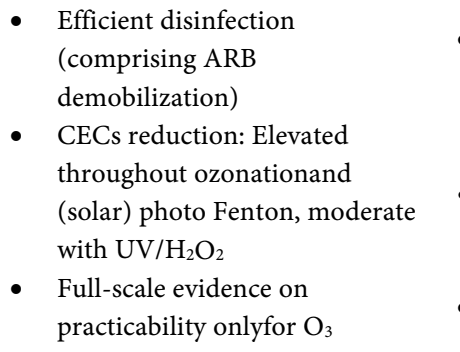 & $\begin{array}{l}\text { - Generation of numerous DBPs } \\
\text { (Nnitrosodimethylamine } \\
\text { (NDMA), bromate) throughout } \\
\text { ozonation } \\
\text { - Production of oxidation } \\
\text { transformation products } \\
\text { throughout AOP and ozonation } \\
\text { - Partial ARGs reduction }\end{array}$ & $\begin{array}{l}\text { - Toxicity trials recommended } \\
\text { NDMA and bromate must be } \\
\text { controlled } \text { inO }_{3} \text { treatment }\end{array}$ \\
\hline e (GAC and UV) & $\begin{array}{ll}\text { - } & \text { Efficient disinfection via UV } \\
\text { Elevated CECs reductionvia } \\
\text { GAC } \\
\text { - } \\
\text { Full-scale evidence on } \\
\text { practicability }\end{array}$ & $\begin{array}{l}\text { - Poor/no reduction of ARB \& } \\
\text { ARGs via GACalone } \\
\text { - } \quad \text { For UV see above, TT a \& b }\end{array}$ & $\begin{array}{l}\text { - Reducing adsorption capacity } \\
\text { with elevating bed volume must } \\
\text { be considered }\end{array}$ \\
\hline $\mathrm{f}(\mathrm{PAC}$ and UV) & $\begin{array}{l}\text { - } \\
\text { - Efficient disinfection via UV } \\
\text { PAC } \\
\text { - Full-scale evidence on } \\
\text { practicability forCEC removal } \\
\text { by PAC }\end{array}$ & $\begin{array}{l}\text { - Poor/no reduction of ARB \& } \\
\text { ARGs via PACalone } \\
\text { - For UV see above, TT a \& b }\end{array}$ & \\
\hline $\begin{array}{l}\mathrm{g}(\mathrm{NF} \text { or RO membrane filtration, } \\
\text { with potential pre-treatment } \\
\text { with MF or UF membranes) }\end{array}$ & $\begin{array}{l}\text { Efficient disinfection for bacteria } \\
\text { (comprising ARB) and protozoa } \\
\text { for all membranes; viruses well } \\
\text { removed by UF, NF \& RO } \\
\text { - } \quad \text { ARGs well removed by NF and } \\
\text { RO } \\
\text { - CECs removal from poor (MF, } \\
\text { UF) to verygood (NF, RO) } \\
\text { following membrane type } \\
\text { - RO and partially also NF reduce } \\
\text { - } \text { salinity }\end{array}$ & $\begin{array}{l}\text { Poor/no reduction of ARGs at } \\
\text { full-scale byMF (for UF some } \\
\text { reduction is expected) } \\
\text { - Poor CECs elimination for MF } \\
\text { and UF } \\
\text { Elevated energy needs for NF } \\
\text { and RO } \\
\text { - Formation of a substantial } \\
\text { concentrate waste stream by NF } \\
\text { and RO } \\
\text { For post UV-C see TT a \& b }\end{array}$ & $\begin{array}{l}\text { Effect of membrane features on } \\
\text { disinfection, ARB, ARG, and } \\
\text { CEC reduction has to be } \\
\text { carefully taken into account in } \\
\text { design } \\
\text { - Consider AOP instead of UV } \\
\text { disinfection ifthe risk of } \\
\text { unknowns and spills is } \\
\text { considered high } \\
\text { Consider high UV doses if } \\
\text { NDMA can be suspected in the } \\
\text { membrane effluent (e.g. } \\
\text { following prior chloramination) }\end{array}$ \\
\hline
\end{tabular}

issue worldwide. For that reason, the objective of this work is to focus on the main results of an excellent review presented lately by Rizzo et al. [1] who presented a technical contribution via suggesting likely advanced treatment choices to make wastewater reuse safer, in particular with regard to the removal of CECs and ARB \& ARGs. They discussed possible BATs for the advanced treatment of urban wastewater involving their benefits and disadvantages.

2) Rizzo et al. [1] deduced that a one advanced treatment technique is not enough to reduce the liberation of chemical CECs and ARB \& ARGs and make 
wastewater reuse for crop irrigation safer; however, an impertinent integration of them (Figure 1) and an appropriate controlling program (Table 1) would be needed. Such reasoning emerges from the attention that each treatment technique possesses its proper weaknesses/drawbacks, as an illustration:

- a biological post-treatment to eliminate oxidation by-products may be needed when ozonation or AOP is employed as advanced treatment;

- ozonation and AOPs need toxicity monitoring due to probable generation of problematic oxidation reaction products;

- adsorption techniques must be pursued by an efficient disinfection method (i.e., UV disinfection);

- if PAC is utilized, a posterior filtration or membrane process has to be added to eliminate the adsorbent particles;

- chemical disinfection is not efficacious in dealing with CECs and ARGs; therefore, it has to be combined with more advanced treatment techniques. Over and above, probable generation of DBPs (i.e., chlorination by-products) must be taken into account, and the next treatment for their elimination is requisite;

- NF or RO membrane technology needs a pre-treatment (i.e., sand filtration) to avoid blocking and a potential solution for the recycling of membrane concentrate.

3) More comparative investigations between various advanced treatment techniques on real wastewater, following diverse criteria (i.e., CECs removal, ARB \& ARGs, toxicity, DBPs, costs) are suggested [1].

4) As seen through this work, there is no miraculous BAT for treating wastewater for water reuse in agriculture. An appropriate combination of many techniques would be suggested following each case.

\section{Conflicts of Interest}

The authors declare no conflicts of interest regarding the publication of this paper.

\section{References}

[1] Rizzo L., Gernjak, W., Krzeminski, P., Malato, S., McArdell, C.S., Perez, J.A.S., Schaar, H. and Fatta-Kassinos, D. (2020) Best Available Technologies and Treatment Trains to Address Current Challenges in Urban Wastewater Reuse for Irrigation of Crops in EU Countries. Science of the Total Environment, 710, Article ID: 136312. https://doi.org/10.1016/j.scitotenv.2019.136312

[2] Ghernaout, D. (2017) Water Reuse (WR): The Ultimate and Vital Solution for Water Supply Issues. International Journal of Sustainable Development, 3, 36-46. https://doi.org/10.11648/j.ijsdr.20170304.12

[3] Ghernaout, D., Elboughdiri, N. and Al Arni, S. (2019) Water Reuse (WR): Dares, Restrictions, and Trends. Applied Engineering, 3, 159-170.

[4] Ghernaout, D., Elboughdiri, N. and Ghareba, S. (2019) Drinking Water Reuse: One-Step Closer to Overpassing the "Yuck Factor". Open Access Library Journal, 6, e5895. https://doi.org/10.4236/oalib.1105895 
[5] Ghernaout, D. (2013) The Best Available Technology of Water/Wastewater Treatment and Seawater Desalination: Simulation of the Open Sky Seawater Distillation. Green and Sustainable Chemistry, 3, 68-88. https://doi.org/10.4236/gsc.2013.32012

[6] Ghernaout, D. (2018) Increasing Trends towards Drinking Water Reclamation from Treated Wastewater. World Journal of Applied Chemistry, 3, 1-9. https://doi.org/10.11648/j.wjac.20180301.11

[7] Ghernaout, D., Alshammari, Y. and Alghamdi, A. (2018) Improving Energetically Operational Procedures in Wastewater Treatment Plants. International Journal of Advances in Applied Sciences, 5, 64-72. https://doi.org/10.21833/ijaas.2018.09.010

[8] Al Arni, S., Amous, J. and Ghernaout, D. (2019) On the Perspective of Applying of a New Method for Wastewater Treatment Technology: Modification of the Third Traditional Stage with Two Units, One by Cultivating Microalgae and Another by Solar Vaporization. International Journal of Environmental Sciences \& Natural Resources, 16, 555934. https://doi.org/10.19080/IJESNR.2019.16.555934

[9] Ghernaout, D. and Elboughdiri, N. (2019) Upgrading Wastewater Treatment Plant to Obtain Drinking Water. Open Access Library Journal, 6, e5959.

https://doi.org/10.4236/oalib.1105959

[10] Ghernaout, D. and Elboughdiri, N. (2020) Antibiotics Resistance in Water Mediums: Background, Facts, and Trends. Applied Engineering, 4, 1-6. https://doi.org/10.4236/oalib.1106003

[11] Ghernaout, D. and Elboughdiri, N. (2020) Removing Antibiotic-Resistant Bacteria (ARB)Carrying Genes (ARGs): Challenges and Future Trends. Open Access Library Journal, 7, e6003. https://doi.org/10.4236/oalib.1106003

[12] Petrie, B., Barden, R. and Kasprzyk-Hordern, B. (2015) A Review on Emerging Contaminants in Wastewaters and the Environment: Current Knowledge, Understudied Areas and Recommendations for Future Monitoring. Water Research, 72, 3-27. https://doi.org/10.1016/j.watres.2014.08.053

[13] Falas, P., Wick, A., Castronovo, S., Habermacher, J., Ternes, T.A. and Joss, A. (2016) Tracing the Limits of Organic Micropollutant Removal in Biological Wastewater Treatment. Water Research, 95, 240-249. https://doi.org/10.1016/j.watres.2016.03.009

[14] Krzeminski, P., Tomei, M.C., Karaolia, P., Langenhoff, A., Almeida, C.M.A., Felis, E., Gritten, F., Andersen, H.R., Fernandes, T., Manaia, C.M., Rizzo, L. and Fatta-Kassinos, D. (2019) Performance of Secondary Wastewater Treatment Methods for the Removal of Contaminants of Emerging Concern Implicated in Crop Uptake and Antibiotic Resistance Spread: A Review. Science of the Total Environment, 648, 1052-1081. https://doi.org/10.1016/j.scitotenv.2018.08.130

[15] Ghernaout D. and Elboughdiri, N. (2019) Water Reuse: Emerging Contaminants Elimination-Progress and Trends. Open Access Library Journal, 6, e5981. https://doi.org/10.4236/oalib.1105981

[16] Rizzo, L., Malato, S., Antakyali, D., Beretsou, V.G., Đolić, M.B., Gernjak, W., Heath, E., Ivancev-Tumbas, I., Karaolia, P., Lado Ribeiro, A.R., Mascolo, G., McArdell, C.S., Schaar, H., Silva, A.M.T. and Fatta-Kassinos, D. (2019) Consolidated vs New Advanced Treatment Methods for the Removal of Contaminants of Emerging Concern from Urban Wastewater. Science of the Total Environment, 655, 986-1008. https://doi.org/10.1016/j.scitotenv.2018.11.265

[17] Ghernaout, D., Elboughdiri, N. and Alghamdi, A. (2019) Direct Potable Reuse: The Singapore NE Water Project as a Role Model. Open Access Library Journal, 6, e5980. 
[18] Ghernaout, D., Elboughdiri, N. and Ghareba, S. (2020) Fenton Technology for Wastewater Treatment: Dares and Trends. Open Access Library Journal, 7, e6045. https://doi.org/10.4236/oalib.1106045

[19] Boshir Ahmed, M., Zhou, J., Hao Ngo, H., Guo, W., Thomaidis, N.S. and Xu, J. (2017) Progress in the Biological and Chemical Treatment Technologies for Emerging Contaminant Removal from Wastewater: A Critical Review. Journal of Hazardous Materials, 323, 274-298. https://doi.org/10.1016/j.jhazmat.2016.04.045

[20] Tiwari, B., Sellamuthu, B., Ouarda, Y., Drogui, P., Tyagi, R.D. and Buelna, G. (2017) Review on Fate and Mechanism of Removal of Pharmaceutical Pollutants from Wastewater Using Biological Approach. Bioresource Technology, 224, 1-12. https://doi.org/10.1016/j.biortech.2016.11.042

[21] Ghernaout, D. (2019) Reviviscence of Biological Wastewater Treatment: A Review. Applied Engineering, 3, 46-55.

[22] Miklos, D.B., Remy, C., Jekel, M., Linden, K.G., Drewes, J.E. and Hübner, U. (2018) Evaluation of Advanced Oxidation Processes for Water and Wastewater Treatment: A Critical Review. Water Research, 139, 118-131. https://doi.org/10.1016/j.watres.2018.03.042

[23] Von Gunten, U. (2018) Oxidation Processes in Water Treatment: Are We on Track? Environmental Science \& Technology, 52, 5062-5075. https://doi.org/10.1021/acs.est.8b00586

[24] Roccaro, P. (2018) Treatment Processes for Municipal Wastewater Reclamation: The Challenges of Emerging Contaminants and Direct Potable Reuse. Current Opinion in Environmental Science \& Health, 2, 46-54. https://doi.org/10.1016/j.coesh.2018.02.003

[25] Marron, E., Mitch, W.A., von Gunten, U. and Sedlak, D.L. (2019) A Tale of Two Treatments: The Multiple Barrier Approach to Removing Chemical Contaminants during Potable Water Reuse. Accounts of Chemical Research, 52, 615-622. https://doi.org/10.1021/acs.accounts.8b00612

[26] Ghernaout, D. (2019) Virus Removal by Electrocoagulation and Electrooxidation: New Findings and Future Trends. Journal of Environmental Science and Allied Research, 2019, 85-90.

[27] Ghernaout, D. (2019) Electrocoagulation and Electrooxidation for Disinfecting Water: New Breakthroughs and Implied Mechanisms. Applied Engineering, 3, 125-133.

[28] Ghernaout, D. (2013) Advanced Oxidation Phenomena in Electrocoagulation Process: A Myth or a Reality? Desalination and Water Treatment, 51, 7536-7554. https://doi.org/10.1080/19443994.2013.792520

[29] Ghernaout, D. and Elboughdiri, N. (2019) Mechanistic Insight into Disinfection Using Ferrate(VI). Open Access Library Journal, 6, e5946.

[30] Ghernaout, D. and Elboughdiri, N. (2020) Electrochemical Technology for Wastewater Treatment: Dares and Trends. Open Access Library Journal, 7, e6020.

[31] Ghernaout, D. and Elboughdiri, N. (2019) Water Disinfection: Ferrate(VI) as the Greenest Chemical: A Review. Applied Engineering, 3, 171-180.

[32] Ghernaout, D. and El-Wakil, A. (2017) Requiring Reverse Osmosis Membranes Modifications: An Overview. American Journal of Chemical Engineering, 5, 81-88.

[33] Ghernaout, D. (2017) Reverse Osmosis Process Membranes Modeling: A Historical Overview. Journal of Civil, Construction and Environmental Engineering, 2, 112-122. 
[34] Ghernaout, D., El-Wakil, A., Alghamdi, A., Elboughdiri, N. and Mahjoubi, A. (2018) Membrane Post-Synthesis Modifications and How It Came about. International Journal of Advances in Applied Sciences, 5, 60-64. https://doi.org/10.21833/ijaas.2018.02.010

[35] Ghernaout, D., Alshammari, Y., Alghamdi, A., Aichouni, M., Touahmia, M. and Ait Messaoudene, N. (2018) Water Reuse: Extenuating Membrane Fouling in Membrane Processes. International Journal of Environmental Chemistry, 2, 1-12. https://doi.org/10.11648/j.ajche.20180602.12

[36] Ghernaout, D. (2019) Brine Recycling: Towards Membrane Processes as the Best Available Technology. Applied Engineering, 3, 71-84.

[37] Ghernaout, D., Ghernaout, B. and Naceur, M.W. (2011) Embodying the Chemical Water Treatment in the Green Chemistry: A Review. Desalination, 271, 1-10. https://doi.org/10.1016/j.desal.2011.01.032

[38] Ghernaout, D. and Naceur, M.W. (2011) Ferrate(VI): In Situ Generation and Water Treatment: A Review. Desalination and Water Treatment, 30, 319-332. https://doi.org/10.5004/dwt.2011.2217

[39] Ghernaout, D. (2017) Environmental Principles in the Holy Koran and the Sayings of the Prophet Muhammad. American Journal of Environmental Protection, 6, 75-79. https://doi.org/10.11648/j.ajep.20170603.13

[40] Ait Messaoudene, N., Naceur, M.W., Ghernaout, D., Alghamdi, A. and Aichouni, M. (2018) On the Validation Perspectives of the Proposed Novel Dimensionless Fouling Index. International Journal of Advances in Applied Sciences, 5, 116-122. https://doi.org/10.21833/ijaas.2018.07.014

[41] Ghernaout, D., Badis, A., Ghernaout, B. and Kellil, A. (2008) Application of Electrocoagulation in Escherichia coli Culture and Two Surface Waters. Desalination, 219, 118-125. https://doi.org/10.1016/j.desal.2007.05.010

[42] Ghernaout, D. (2017) Microorganisms' Electrochemical Disinfection Phenomena. EC Microbiology, 9, 160-169.

[43] Ghernaout, D., Touahmia, M. and Aichouni, M. (2019) Disinfecting Water: Electrocoagulation as an Efficient Process. Applied Engineering, 3, 1-12.

[44] Ghernaout, D. and Elboughdiri, N. (2020) Is Not It Time to Stop Using Chlorine for Treating Water? Open Access Library Journal, 7, e6007.

[45] Ghernaout, D., Naceur, M.W. and Aouabed, A. (2011) On the Dependence of Chlorine by-Products Generated Species Formation of the Electrode Material and Applied Charge during Electrochemical Water Treatment. Desalination, 270, 9-22. https://doi.org/10.1016/j.desal.2011.01.010

[46] Ghernaout, D., Moulay, S., Ait Messaoudene, N., Aichouni, M., Naceur, M.W. and Boucherit, A. (2014) Coagulation and Chlorination of NOM and Algae in Water Treatment: A Review. International Journal of Environmental Monitoring and Analysis, 2, 23-34.https://doi.org/10.11648/j.ijema.s.2014020601.14

[47] Ghernaout, D. (2017) Water Treatment Chlorination: An Updated Mechanistic Insight Review. Chemistry Research Journal, 2, 125-138.

[48] Ghernaout, D., Alghamdi, A., Aichouni, M. and Touahmia, M. (2018) The Lethal Water Tri-Therapy: Chlorine, Alum, and Polyelectrolyte. World Journal of Applied Chemistry, 3, 65-71. https://doi.org/10.11648/j.wjac.20180302.14

[49] Boucherit, A., Moulay, S., Ghernaout, D., Al-Ghonamy, A.I., Ghernaout, B., Naceur, M.W., Ait Messaoudene, N., Aichouni, M., Mahjoubi, A.A. and Elboughdiri, N.A. (2015) New Trends in Disinfection by-Products Formation upon Water Treatment. 
Journal of Research \& Developments in Chemistry, 2015, Article ID: 628833. https://doi.org/10.5171/2015.628833

[50] Ghernaout, D. and Ghernaout, B. (2010) From Chemical Disinfection to Electrodisinfection: The Obligatory Itinerary? Desalination and Water Treatment, 16, 156-175. https://doi.org/10.5004/dwt.2010.1085

[51] Ghernaout, D. (2018) Disinfection and DBPs Removal in Drinking Water Treatment: A Perspective for a Green Technology. International Journal of Advances in Applied Sciences, 5, 108-117. https://doi.org/10.21833/ijaas.2018.02.018

[52] Ghernaout, D., Alghamdi, A. and Ghernaout, B. (2019) Microorganisms' Killing: Chemical Disinfection vs. Electrodisinfection. Applied Engineering, 3, 13-19.

[53] Ghernaout, D. and Ghernaout, B. (2012) On the Concept of the Future Drinking Water Treatment Plant: Algae Harvesting from the Algal Biomass for Biodiesel Production: A Review. Desalination and Water Treatment, 49, 1-18. https://doi.org/10.1080/19443994.2012.708191 